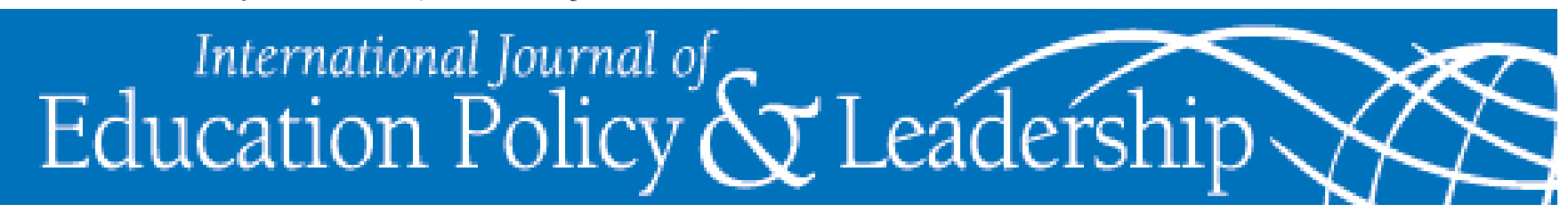

\title{
Trends in Technology Planning and Funding in Florida K-12 Public SCHOOLS
}

\author{
Albert Dieter Ritzhaupt \\ University of North Carolina at Wilmington \\ TinA N. HOHLFELD \\ University of South Florida \\ ANN E. BARRON \\ University of South Florida \\ KATE KEMKER \\ Florida Department of Education
}

\begin{abstract}
This empirical research investigates trends in technology planning and funding in Florida's K-12 public schools between the 2003-04 and 2005-06 academic years. Survey items that focused on funding and planning issues on Florida's statewide school technology integration survey were analyzed using logistic models. Results indicate a significant increase in the number of schools revising their technology plans on a regular basis; a significant increase in the frequency with which Florida's K-12 public schools are seeking funding for technology-related initiatives; a significant increase in parent, administrator, teacher, and student involvement in the technology planning process; and a significant decline in adequate funding for software and hardware needs. In addition, schools with low proportions of economically disadvantaged students sought and were awarded significantly more funds from donations and federal and state grants. Implications for educational leadership and policy are provided.
\end{abstract}

Ritzhaupt, A. D., Hohlfeld, T. N., Barron, A. E., \& Kemker, K. (2008). Trends in Technology Planning and Funding in Florida K-12 Public Schools. International Journal of Educatiuon Poicy and Leadership 3(8). Retrieved [DATE] from http://www.ijepl.org.

\section{Introduction}

According to the 2007-08 Florida State Government Technology Investment Forecast, Florida allocated over $\$ 1.25$ billion to the State Board of Education to spend on educational technology initiatives during fiscal year 2008 (Mathison, 2007). In addition to receiving state funding, Florida's K-12 public schools obtain technology funds from federal and private sources. For example, the No Child Left Behind, Title II, Part D Enhancing Education Through Technology program allocated over $\$ 88$ million to Florida's school districts since 2004 (Lemke, Wainer, \& Haning, 2006).
With this magnitude of funding directed toward educational technology initiatives, it is critical for legislators, administrators, parents, students, and teachers to understand the allocation processes. The Koret Task Force's report noted that "Florida is far ahead of other states because it has a statewide comprehensive finance database that provides uniform financial information for each school and district in the state" (Peterson, 2006, p. 256); however, this report recommended that the funding policies within Florida school districts be examined.

The processes involved in technology planning and funding are also pertinent to colleges of education and

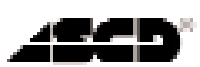

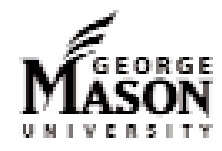


accrediting bodies such as the National Council for Accreditation of Teacher Education (NCATE). Training for teachers and administrators should include the current practices and challenges in technology integration, planning, and funding (Vanatta, 2000). Indeed, one of the performance indicators for the National Educational Standards for Administrators, set forth by the Technology Standards for School Administrators (TSSA) Collaborative, states that educational leaders should "maintain an inclusive and cohesive process to develop, implement, and monitor a dynamic, long-range, and systemic technology plan to achieve the vision" (ISTE, 2002, p. 4).

\section{Background}

For more than 20 years, the Florida Department of Education (FLDOE) Office of Instructional Technology has collected information from Florida school districts about their access to information and communication technology. Historically, the survey has focused on "counting the boxes"-reporting how many computers are available in each school, along with the age and specifications of each computer.

Between the 1992-93 and 2001-02 school years, Florida experienced growth in public school population of over 25 percent, and this trend is expected to continue (Florida Department of Education, 2005). This increase has challenged the capacity of the infrastructure and resources as well as the human capital of Florida K12 public schools. In response to these challenges, educational technology leaders and the FLDOE have expressed the need to modify and extend the state technology survey to capture more meaningful information about technology integration and capacity in Florida's schools. Content experts from across the state were assembled in 2002 to define key elements that would be relevant for decision makers.

Using surveys for assessing technology integration in previous large-scale technology integration studiessuch as those of Becker (2001); Benner, Shapley, Heikes, $\&$ Pieper (2002); and the U.S. Department of Education (2002) — as a starting point, strands and categories for the modified survey were identified and defined. After extensive reviews and validation studies, the modifications culminated in the System for Technology Accountability and Rigor (STAR) survey (Florida Department of Education, 2007). The STAR survey, which was pilot-tested in 2002 and fully implemented in 2003, is organized into five sections: digital learning environment, instructional leadership, Florida digital educators, access to technology, and infrastructure and support. This article focuses on survey items from the instructional leadership section of the survey that focused on funding and planning issues. In particular, the purpose of this research was to examine differences in the trends in technology planning and funding of the public schools in Florida by their socioeconomic status (SES) from the 2003-04 academic year through the 2005-06 academic year.

\section{Technology Planning and Funding}

In the current era of escalating demands for resources to meet the increasingly complex task of educating today's students, it is important to invest in both human and capital resources that will enhance efficiency and effectiveness (Thompson, Simonson, \& Hargrave, 1996). Two well-recognized antecedents to the successful integration of information and communication technology include the planning process that surrounds technology integration and how schools fund technology-related initiatives (Anderson \& Dexter, 2000; U.S. Department of Education, 2002; Whitehead, Jensen, \& Boschee, 2003).

Successful integration of technology throughout a school system should be consistent with the school district's overall educational mission, vision, and strategic plan (TSSA Collaborative, 2001). "The intent of this [mission and vision] component is to provide a perspective on what the district considers to be vital and critically important in relation to technology use and improving student performance" (Florida Department of Education, 2004 , p. 1). Technology plans are not an add-on but an integral part of the school improvement plan (November, Staudt, Costello, \& Huske, 1996). Technology plans need to consider the long-term needs of the organization in order to provide for adequate supports-the equipment, professional development, and technical support required for integrating technology into the curriculum and delivering instruction in the classroom (Anderson \& Dexter, 2000; White, Ringstaff, $\&$ Kelley, 2002). In most cases, the technology plan formally articulates the vision and blueprint for schoolwide technology integration.

Effective technology plans include policy development processes; reviews of current status and needs assessments; plans for deployment and implementation of technology; procedure for approval; provision for funding, support, and staff training; and an evaluation, review, and revision process (Anderson \& Dexter, 2000; U.S. Department of Education, 2002). Technology plans must consider the needs of participants at all levels with- 
in the school and provide resources and support structures to adequately meet these needs. Bringing together a technology planning committee should be the first step in the planning process (November et al., 1996). As noted by Anderson and Dexter (2000), "A formal technology committee, with representation from teachers, administrators, parents, and students, can be very effective" (p. 3).

A vital aspect of creating and assessing a successful technology plan is considering the strategies that will fund it. Imperatives for the success of the technology integration initiative include ongoing funding support for capital expenses of infrastructure and hardware, maintenance expenses such as software upgrades, and human capital of technology support personnel (Anderson \& Becker, 2001). Adequate funding is essential for the initial investment in hardware, software, and training. However, funding for the ongoing support, upgrade, and maintenance of technology is crucial for realizing its positive impact. Nevertheless, as Fishman, Pinkard, and Bruce (1998) point out, schools too often focus technology planning on the most efficient ways to obtain hardware but fail to plan for teacher professional development and how this hardware will be used. These misaligned foci treat technology integration as "a discrete administrative task, separate from instructional or curricular concerns" (Fishman et al., 1998, p. 100). Thus, it is crucial to use established processes and models for planning and funding effective technology initiatives, so that both access and meaningful use are addressed.

Although funding can be an issue for all schools, it can be even more critical for schools with low socioeconomic status. Anderson and Dexter (2000) found that although schools with the highest proportion of economically disadvantaged students were more likely to receive a grant for the initial technology acquisition, these same schools were often incapable of developing the "exceptional financing methods' such as corporate donations and parent fund-raising activities" necessary for their continuance (p. 3). As a consequence, if schools with high proportions of economically disadvantaged students cannot maintain the prerequisites for technology integration, their students may not be able to acquire the positive benefits from closing the digital divide and narrowing the achievement gap.

Barnett (2001) emphasizes the importance of frequent monitoring and assessment of the technology planning process. Regular accountability reviews examining the match between the needs assessments and the outcomes provide measures to track the progress of the technology plan implementation (U.S. Department of Education, 2002). With ongoing formative reviews, schools can adjust their technology initiatives to enhance successful outcomes for students.

\section{Method}

\section{Instrument and Sample}

Beginning with the 2003-04 school year, the STAR survey has been administered to all public schools in Florida annually. During the fall term, the FLDOE asks principals and technology coordinators from every school in the state to participate in the survey. A nine-week window is provided for the school-based personnel to complete the survey and for district-level personnel to verify the data.

The technology planning and funding items analyzed in this study were completed by a designated principal at each school. Eight survey items were selected for analysis in this study, on the basis of their appropriateness to address technology planning and funding trends (see Appendix for survey items). The items were extracted from the instructional leadership section of the survey, which has high internal consistency reliability (K-R $20=$ .83).

The survey response rate was very high: 97 percent $(N=2514)$ in 2003-04; 96 percent $(N=2553)$ in 2004-05; and 97 percent $(N=2658)$ in 2005-06. In order to represent the population of typical K-12 public schools in Florida for the trend analyses of this study, only the responses from elementary, middle/junior, and high schools that participated all three years were included in this analysis. Special purpose public K-12 schools (e.g., charter, private, and vocational schools), and combination schools (schools housing multiple levels) were intentionally excluded. This reduced the final sample to $N=2482$ as a representation of the typical public K-12 schools in the state of Florida. In the subsequent discussion, the use of the term "Florida K-12 public schools" refers to the sample in this study. Because the survey instrument was modified slightly from year to year to capture changing aspects of technology and education, some of the technology planning and funding items were inconsistent in format across the three years. Therefore, some of the trends analyzed in this study include items from the surveys completed in the 2004-05 and 2005-06 academic years only. 


\section{Data Analysis}

The first step was to map the items across the three years. Next, some of the items that had undergone revisions were either discarded or recoded. Only items that were categorical in nature were analyzed. The differences in sample percentages were tested using logistic models with repeated measures for categorical variables_-rather than the Pearson chi-square-for each item descriptor because it allows the overall test of significance to be disaggregated into specific contrasts between pairs of years for the same sample of schools. Separate contrasts were run to determine whether the changes were significant between 2003-04/2004-05, 2003-04/2005-06, and 2004-05/2005-06 for all Florida K-12 public schools.

Next, the socioeconomic status (SES) of each school, as determined by the proportion of students on free or reduced-price lunch programs, was merged with the survey data and schools were rank-ordered in percentiles. The data were then subdivided into schools with greatest proportions of students on free or reduced-priced lunch programs (30 percent) to represent low-SES schools and schools with the lowest proportions of students on free or reduced-price lunch programs (30 percent) to represent high-SES schools. Thus, only 60\% of the remaining sample $(N=1480)$ was used in the analysis SES in Florida's K-12 public schools. A series of two-way factorial logistical models were used with time serving as a repeated measure and SES serving as a between-subjects condition.

\section{Results and Discussion}

\section{Technology Planning}

This study investigated several aspects of technology planning, including frequency of revisions, alignment with other district plans and initiatives, the primary focus of the technology plans, and stakeholders on the technology planning committees.

\section{Frequency of revisions}

A technology plan should be revised and updated "at least once a year to provide evaluation of its usefulness" (November et al., 1996, p. 5). In fact, the FLDOE states that an essential component of the technology plan is the program evaluation, which should be conducted midyear in order to make adjustments in response to new developments and opportunities (Florida Department of Education, 2004). The results of the survey show that, indeed, most Florida K-12 public schools are revising their technology plans on an annual basis
(2005-06 = 86 percent). In fact, as illustrated in Table 1 (page 11), the percentage of Florida K-12 public schools revising their technology plans on an annual basis increased each year during the three-year period of this study. The increase went from 70 percent in 2003 to 73 percent in 2004 and 86 percent in 2005-06 $\left(\chi^{2}=\right.$ $118.49, p<.0001)$.

Further, there was a decreasing trend in the number of Florida K-12 public schools reporting "no set revision policy" for their technology plan-from 9 percent in 2003-04 to 8 percent in 2004-05 and 5 percent in 2005-06 ( $\left.\chi^{2}=14.33, p=0.0002\right)$-as well as a decrease in the percentage of schools waiting three to five years to revise their technology plans. These results highlight the growing importance of information and communication technology in school planning and indicate that more school administrators have established a clear and frequent policy for the technology review and planning process.

\section{Technology plan alignment}

Analysis revealed that school technology plans in Florida undergo varying levels of revision and approval from a mixture of leadership bodies (see Table 2, page 11). The majority of Florida K-12 public schools continue to align their technology plans with their districts' technology plans, school advisory councils, and school improvement plans. Over the past few years, the number of schools that align their technology plan with the district's plans has increased significantly-from 84 percent in 2003-04 to 90 percent in 2005-06 $\left(\chi^{2}=18.3, p<\right.$ $.0001)$. However, a significant decreasing trend occurred in the number of schools seeking approval for their technology plans from a school advisory council-from 69 percent in 2003-04 to 63 percent in 2005-06 ( $\chi^{2}=$ $11.81, p=.0006)$. In addition, a significant decreasing trend occurred in the number of schools that align their technology plan as part of the school's improvement plan-from 80 percent in 2003-04 to 72 percent in 2005-06 ( $\left.\chi^{2}=21.21, p<.0001\right)$.

\section{Focus of technology plan}

School administrators were also asked to indicate the primary focus of their technology plans (see Table 3, page 12). Although schools may have been concerned with and addressed more than one of the issues listed, they could select only one option as their primary focus for this particular item. Results indicate a significant increase in the number of schools whose technology plans focus primarily on providing access and skills for all stu- 
dents-from 11 percent in 2003-04 to 47 percent in 2005-06 $\left(\chi^{2}=508.83, p<.0001\right)$.

Significant decreases appeared in the number of schools with a primary focus of integrating technology into subject-area instruction-from 65 percent in 2003-04 to 44 percent in 2005-06 $\left(\chi^{2}=131.16, p<\right.$ .0001 ) and in the number of schools with a focus on using technology for select groups such as gifted or special education students-from 13 percent in 2003-04 to 0 percent in 2005-06 $\left(\chi^{2}=162.31, p<.0001\right)$. These results provide evidence that schools are more concerned with providing access and skills to the entire student population than to select groups, and the focus appears to be growing across the curriculum rather than in specific subject areas. Another interesting aspect of the technology planning focus was the significant changes related to procuring and maintaining hardware and software. The number of schools with this aspect as their primary focus decreased from 10 percent in 2003-04 to 4 percent in 2004-05; then it rebounded to 6 percent in 2005-06.

\section{Stakeholder involvement in technology planning} Involving all necessary stakeholders in creating the technology plan is crucial for a successful technology integration initiative, because diverse teams supply the variety of viewpoints, skills, and communications that are required to encourage acceptance and implementation (Billig, Sherry, \& Havelock, 2005; White et al., 2002). Although the 2003-04 STAR survey did not include an item soliciting information about the individuals involved in the technology planning process, results from the two more recent academic terms indicate that Florida K-12 public schools have involved many different stakeholders in the technology planning process, including administrators, business leaders, community members, consortia, district technology leaders, parents, students, teachers, and technology specialists.

The percentage of business leaders, community members, and district technology specialists included in the technology planning process appears to have remained relatively constant from the 2004-05 to the 2005-06 school year (see Table 4, page 12). However, there were increasing trends in the number of parents $\left(\chi^{2}\right.$ $=4.23, p=.0397)$, teachers $\left(\chi^{2}=11, p=.0009\right)$, administrators $\left(\chi^{2}=6.26, p=.0124\right)$, and students $\left(\chi^{2}=11.53\right.$, $p=.0007)$ involved in the technology planning process across the years.

\section{Technology Funding}

The survey items related to technology funding focused on hardware and software needs, primary funding sources for Florida K-12 public schools, and information about other funding sources.

\section{School hardware and software funding needs}

Florida K-12 public schools reported funding status and needs with respect to both hardware and software (see Table 5, page 13). Their responses were based on a continuum related to being able to maintain the current level of technology. On the negative side of the continuum, schools could indicate one of two conditions: either they did not have adequate funding, or they could afford some expenditure but not enough to maintain their level of technology. The positive side of the continuum had two additional options: schools could maintain their level of technology with limited purchases or maintain their level of technology and afford all purchases for desired growth. The two descriptors indicating a lack of funding to support current level of technology were combined as "cannot maintain current level of technology," and the other three descriptors were combined as "maintain current level of technology."

Results showed a statistically significant increase in the number of schools reporting inadequate funding for both hardware $\left(\chi^{2}=231.17, p<.0001\right)$ and software $\left(\chi^{2}\right.$ $=121.39, p<.0001)$ from 2003-04 to 2005-06. Conversely, there was a significant decline in the percentage of schools reporting they could maintain their current level of technology-from 80 percent in 2003-04 to 56 percent in 2005-06 for hardware $\left(\chi^{2}=231.17, p<\right.$ $.0001)$ and from 76 percent in 2003-04 to 58 percent in 2005-06 for software needs $\left(\chi^{2}=121.39, p<.0001\right)$. These results indicate that a growing number of Florida K-12 public schools lack sufficient hardware and software funding to meet organizational needs.

\section{Primary funding sources}

Understanding needs is only one aspect of complex school technology funding phenomena. Consideration of the sources of revenue for funding technology initiatives is also an imperative. Primary funding sources were not included as an item in the 2003-04 release of the STAR survey, and changes were rendered from 2004-05 to 2005-06. The options that remained constant from 2004 to 2006 were included in this analysis.

Generally, technology funding sources in Florida K-12 public schools include A+/School recognition (a funding program that acknowledges schools that are achieving and showing improvement), profits from school ventures such as vending machines, Title I funds, and School Improvement funds (see Table 6, page 13). Although funding sources remained fairly stable, this 
study showed significant increases in the percentage of schools realizing profits from school ventures $\left(\chi^{2}=4.37\right.$, $p=.0366)$ and Title I $\left(\chi^{2}=4.07, p=.0437\right)$ from 2004-05 to 2005-06. Significantly fewer schools indicated having no other funds earmarked for technology initiatives $\left(\chi^{2}=35.8, p<.0001\right)$.

\section{Ancillary technology funding sources}

The external, nontraditional technology funding sought by and awarded to Florida K-12 public schools includes an assortment of sources. Although Florida K-12 public schools seek funds from a variety of external sources, the funds are not always awarded. The data from the survey indicate that Florida K-12 public schools sought technology funding from business partnerships; donations; fund-raisers; district, state, federal and private grant (see Table 7, page 14).

From 2003-04 to 2005-06, a significant decline ( $\chi^{2}$ $=8.095, p=.004)$ occurred in the number of schools reporting that they did not seek additional technology funding. This interesting trend shows that more schools are seeking external funding to serve their technology initiatives. Although there was a significant decrease in the percentage of schools seeking funding from federal and state grants - from 33 percent in 2003-04 to 25 percent in $2005-06\left(\chi^{2}=39.75, p<.0001\right)$-federal and state grants yielded the second-highest percentage of funds awarded to Florida $\mathrm{K}-12$ public schools in this study, at 23 percent in 2005-06. A similar pattern exists for fund-raisers; whereas the percentage of schools using them to generate technology revenue declined $\left(\chi^{2}=\right.$ $18.83, p<.0001)$, fund-raisers yielded the highest percentage of revenue (24 percent) in 2005-06.

In the most recent school year, 28 percent of Florida $\mathrm{K}-12$ public schools in the study sought funding from donations, with 23 percent of the schools reporting successfully acquiring the funds (see Table 7, page 14). During the same year, 26 percent of schools sought technology funding through business partnerships, yet only 15 percent of those funds were awarded. The 5 percent differential between the funds sought and funds awarded by donations, as opposed to the 11 percent differential resulting from business partnerships, may be an indication that, on average, donations yield more frequent awards.

\section{Socioeconomic Status and Technology Funding}

Of particular concern for this research were the relationships between schools' socioeconomic status (SES) and school hardware and software funding needs. In addi- tion, the research investigated relationships between SES and other funding sources, such as donations and fundraising activities.

\section{SES and hardware and software funding}

School socioeconomic status was related to a number of technology funding indicators from the 2003-04 school year to the 2005-06 year. Table 8 (page 14) illustrates the effect of SES on both hardware and software funding needs.

As can be gleaned, research results show a significant difference between the percentage of high- and low-SES schools reporting having enough funding to maintain current levels of hardware technology needs $\left(\chi^{2}=\right.$ $288.85, p<.0001)$. Initially, high-SES schools reported a significantly higher percentage of funds for meeting hardware technology needs; however, in subsequent years (2004-05 to 2005-06), the percentage of high- and low-SES schools having funds to maintain current levels of hardware technology needs were similar. Similarly, there was an interaction effect $\left(\chi^{2}=11, p=.004\right)$ between SES and time in this category, indicating that over time the trends for high-SES and low-SES schools were significantly different.

In terms of software funding needs, the results were similar. Main SES effects became visible for the percentage of schools reporting they could not maintain current technology levels $\left(\chi^{2}=171.97, p<.0001\right)$, with a slightly higher percentage (1\%) of low-SES schools in this category during 2003-04. An SES main effect was also detected when examining the percentage of schools that reported they could maintain current levels of technology $\left(\chi^{2}=171.97, p<.0001\right)$. A greater percentage of lowSES schools in 2005-06 indicated they could maintain current levels of technology (low-SES $=60$ percent vs. high-SES $=56$ percent).

\section{SES and ancillary funding sources}

Primary funding sources were purposely excluded from the analysis because funding programs such as Title I specifically address schools with low-SES students as a determinant of funding. In terms of ancillary technology funding sources, SES had a significant main effect in every category except technology funds sought by business partnerships and technology funds awarded by private grants. Further, no interaction effects surfaced between SES and time for the three school years covered in the study. In terms of federal and state grants, it appears that low-SES schools sought $\left(\chi^{2}=71.02, p<\right.$ $.0001)$ and were awarded $\left(\chi^{2}=123.72, p<.0001\right)$ funds 
much more frequently over the three academic years. However, donations appear to have a much greater impact in high-SES schools in terms of both funds sought $\left(\chi^{2}=\right.$ $27.19, p<.0001)$ and funds awarded $\left(\chi^{2}=78.86, p<\right.$ $.0001)$.

Fund-raising is sought $\left(\chi^{2}=126.5, p<.0001\right)$ and acquired $\left(\chi^{2}=155.1, p<.0001\right)$ significantly more often by high-SES schools than low-SES schools. These trends are consistent with research previously conducted by Anderson and Becker (2001). A final important note involves the main SES effect in the overall percentage of high-SES schools seeking additional technology funding $\left(\chi^{2}=18.6, p<.0001\right)$ when compared to low-SES schools. Low-SES schools appear to be significantly less likely to seek additional technology funding (see Table 9, page 15).

\section{Conclusions and Implications}

Interpretation of these results must be viewed within the limitations of the research. This study was conducted with the use of secondary data collected by the FLDOE. Because of the dynamic nature of information and communication technology, the design of the STAR survey is continually revised to collect relevant information needed for decision making. Clarification of the items and movement of the items within the survey may have affected the responses. Thus, the constructs used in the analysis may have changed over time. Further, the technology indicators are essentially measures that are self-reported by a principal, a school technology specialist, or another designated educator.

What can we conclude from these trends? This research analyzed technology planning and funding trends in Florida $\mathrm{K}-12$ public schools from 2003-04 through 2005-06. The results indicate there was a significant increase in the frequency of schools' revising their technology plans, a significant increase in the number of Florida $\mathrm{K}-12$ public schools seeking funding for technology-related initiatives, and a significant overall decline in adequate funding for meeting software and hardware needs. Results also indicate an increasing trend in the involvement of parents, teachers, and students in the technology planning process, yet the involvement of other stakeholders has remained relatively constant. A similar upward trend occurred in the percentage of Florida K-12 public schools using Title I and profits from ventures for technology needs.

The results are clear in suggesting that administrators and other key stakeholders are investing an increasing amount of time in planning the integration of information and communication technology into the curriculum and seeking funding to support these costly initiatives. Time, like any other resource, is limited and must be judiciously applied to a myriad of school-related activities. Meanwhile, trends show that technology planning is slowly involving more parents, teachers, and students. Because school leaders want to consider the needs of participants at all levels within the school, they may be actively reaching out to include families and teachers in the educational process (Anderson \& Dexter, 2000; November et al., 1996). This increased emphasis on school technology planning may be a result of better direction and more useful information (e.g., the STAR survey) provided by state-level officials to assist school leaders since the 2003-04 school year.

In an alarming trend, more and more Florida K-12 public schools are reporting insufficient hardware and software funds to maintain current technology levels. The introduction of one technology will inevitably spur the necessity of another (Kranzberg, 1986). Consequently, an increasing percentage of Florida K-12 public schools are seeking funding from both traditional and nontraditional sources to fund technology needs. Surprisingly, low-SES schools reported the same insufficient funding levels as high-SES schools in 2004-05 and 2005-06, yet they seek less additional funding than do high-SES schools.

Research has demonstrated that educational technology has the potential to improve teaching and learning when a school develops a plan that incorporates thoughtful planning and appropriate funding to make its vision a reality (Anderson \& Becker, 2001). Because funding needs appear to be increasing over time, careful planning can help control these investments. Legislators, administrators, parents, students, teachers, and other key stakeholders must have a strong understanding of the processes involved in technology planning and the sources for securing funds for these initiatives.

\section{Implications for Educational Policy and Leadership}

Based on its results and a review of literature, this research provides some recommendations to school, district, and state educational administrators. These recommendations should best be thought of as guiding principles rather than implementation plans or details.

\section{Recognize that funding is temporary and needs are ongoing.}

Initial costs associated with hardware and software represent only a fraction of the cost of ongoing school technology needs (Fishman et al., 1998; Whitehead et al., 2003). Further, school technology costs are multilevel and are shared by schools, school districts, and the state. Software must be updated; hardware quickly becomes obsolete; teachers need professional development; and teachers, stu- 
dents, and administrators need ongoing technical assistance (Anderson \& Becker, 2001; Thompson et al., 1996). Funding technology is unlike funding library books or other all-purpose school resources (Fishman et al., 1998). Technology is a recurring cost, and technology planning must account for these ongoing expenditures.

\section{Seek technology funding from multiple sources.}

Because schools have continuous needs for technology resources, school administrators should seek additional funding through multiple and flexible sources (Anderson $\&$ Dexter, 2000; Florida Department of Education, 2007; U.S. Department of Education, 2002). This research demonstrates that funding is not always awarded; however, without attempting to secure outside funding, no additional monies will be made available for technology investments. Aside from fund-raisers and business partnerships, school administrators must empower and encourage teachers to apply for additional private, feder$\mathrm{al}$, and state grants that are aligned with school objectives (Vanatta, 2000). But administrators need to be mindful of grant requirements that may place additional strain on the infrastructure and time resources of school personnel, and they must balance such requirements with the monetary benefits and willingness of teachers to manage them. In particular, school administrators serving communities with the greatest numbers of economically disadvantaged students should explore federal and private grant opportunities, since many of these funding programs target these populations. This research shows that schools with higher levels of economically disadvantaged students are seeking ancillary technology funding significantly less often than schools with wealthier populations. Therefore, policymakers should actively recruit schools with the greatest numbers of economically disadvantaged students into programs that help school administrators match their schools' needs with funding opportunities.

\section{Infuse technology planning into standard school operations.}

Results suggest that more than 85 percent of the schools in this study are now revising technology plans on at least an annual basis. Experts recommend annual revisions (November et al., 1996; Barrett, 2001) with intermittent reevaluations. More frequent monitoring of technology needs and adjusting the plan for integrating new grants and programs should occur as regular administrative activities, with the involvement of all relevant stakeholders. Moreover, technology planning should be aligned with district technology plans and school advisory councils, and be integrated into planning of school curriculum (TSSA Collaborative, 2001). Misaligned technology plans might result in inappropriate spending (e.g., not purchasing all components necessary for successful implementation of the technology) or unfunded technology initiatives.

\section{Compose technology steering committees with diverse stakeholders.}

Technology planning should engage multiple stakeholders in a decision-making process with informed practices (Billig et al., 2005; Brazer \& Keller, 2006; White et al., 2002). To include the diverse perspectives, this technology steering committee should include students, teachers, administrators, parents, and other community stakeholders (November et al., 1996; Anderson \& Dexter, 2000). Approximately 90 percent of the schools in this study include teachers, administrators, and school technology specialists in the planning process. Far fewer schools include parents, students, district technology coordinators, and active community leaders in technology planning. These stakeholders not only serve to meet community and school needs but also may initiate more technology funding opportunities (e.g., parents and community members may engage in fund-raising initiatives and obtaining matching funds from corporate donations).

\section{Include professional development for key stakehold- ers.}

School districts and state boards of education should provide professional development opportunities to key stakeholders on securing additional technology funding and the planning process surrounding school technology integration, including potential sources and best practices for managing the funding (Vanatta, 2000). Support of open forums for these stakeholders to share experiences across schools, school districts, and states is necessary to facilitate the establishment of best practices and would enhance stakeholder decision making. Because of the many stakeholders involved and the many funding sources available, professional development is a necessity for successful integration.

\section{Establish an effective measurement system.}

State departments of education need a mechanism to systematically measure the technology funding needs and trends within schools and school districts. Florida has had a system in place to measure these issues since the 2002-03 school year. State departments of education should seek recommendations from previous large-scale 
studies on technology integration (e.g., Becker, 2001; Benner et al., 2002), assemble relevant educational technology leaders and administrators with measurement expertise to define key elements, and develop a systematic program to capture meaningful information about technology integration within schools. Only with valid and reliable measurements can responsible decision making be possible. Furthermore, having a measurement system in place would provide a mechanism to compare trends between states, allowing researchers to help identify best practices for planning and funding technology initiatives.

\section{References}

Anderson, R. E., \& Becker, H. J. (2001). School investments in instructional technology (Report \#8). Irvine, CA: University of California, Center for Research on Information Technology and Organizations.

Retrieved December 1, 2007, from http://www.crito.uci.edu/tlc/html/findings.html

Anderson, R. E., \& Dexter, S. L. (2000). School technology leadership: Incidence and impact (Report \#6).

Irvine, CA: University of California, Center for Research on Information Technology and Organizations. Retrieved December 10, 2007, from http://www.crito.uci.edu/tlc/html/findings.html

Barnett, H. (2001). Successful K-12 technology planning: Ten essential elements. Syracuse, NY: ERIC Clearinghouse on Information and Technology. (ERIC Document Reproduction Service No. ED457858)

Becker, H. J. (2001, April). How are teachers using computers in instruction? Paper presented at the American Educational Research Association, Seattle, WA.

Benner, A. J., Shapley, K. S., Heikes, E. J., \& Pieper, A. M. (2002, September). Technology Integration in Education (TIE) initiative statewide survey report. Texas Center for Educational Research. Retrieved December 10, 2007, from http://www.tcer.org/research/index.aspx

Billig, S. H., Sherry, L., \& Havelock, B. (2005). Challenge 98: Sustaining the work of a regional technology initiative. British Journal of Educational Technology, 36(6), 987-1003.

Brazer, S. D., \& Keller, L. R. (2006). A conceptual framework for multiple stakeholder educational decision making. International Journal of Education Policy and Leadership, 1(3). Retrieved December 7, 2007, from http://www.ijepl.org
Fishman, B., Pinkard, N., \& Bruce, C. (1998). Preparing schools for curricular reform: Planning for Technology vs. Technology Planning. In A. Bruckman, M. Guzdial, J. Kolodner, \& A. Ram (Eds.), International Conference on the Learning Sciences (pp. 98-104). Atlanta, GA: AACE.

Florida Department of Education. (2004). District technology plans: Essential components and e-rate plan criteria. Retrieved August 3, 2008, from http://www.fldoe.org/BII/Instruct_Tech/downloads/EssentialComponents.pdf

Florida Department of Education (2005). Change and response to change in Florida's public schools. Tallahassee, FL: Education Information and Accountability Services. Retrieved August 3, 2008, www.fldoe.org/eias/eiaspubs/pdf/changes0207.pdf

Florida Department of Education (2007). System for Technology Accountability and Rigor (STAR) technology resource. Retrieved December 10, 2007, from http://www.flinnovates.org/

Kranzberg, M. (1986). Technology and history: "Kranzberg's Laws." Technology and Culture, 27(3), 544-560.

ISTE-International Society for Technology in Education. (2002). National educational technology standards for administrators. Retrieved December 10, 2007, from http://cnets.iste.org/administrators

Lemke, C., Wainer, A., \& Haning, N. (2006). National trends: Enhancing education through technology, No Child Left Behind Title II-D-year three in review. State Educational Technology Directors Association. Retrieved December 10, 2007, from http://www.ecs.org/html/Document.asp?chouse$\mathrm{id}=6830$

Mathison, P. J. (2007). 2007-08 Florida state government technology investment forecast. Philadelphia, PA: pjmathison.com. Retrieved August 4, 2008, from http://www.pjmathison.com/pjm_fy0708fl_gtf.pdf

November, A., Staudt, C., Costello, M. A., \& Huske, L. (1996). Critical issue: Developing a school or district technology plan. Retrieved January 1, 2007, from North Central Regional Educational Laboratory Retrieved from http://www.ncrel.org/sdrs/areas/issues/methods/tech nlgy/te300.htm

Peterson, P. (Ed.). (2006). Reforming education in Florida: A study prepared by the Koret Task Force on K-12 Education. Stanford, CA: Hoover Institution, Stanford University. Retrieved November 22, 2006, www.hoover.org/publications/books/3895672.html 
TSSA Collaborative. (2001). Technology standards for school administrators. Retrieved December 10, 2007, from http://www.ncrtec.org/pd/tssa

Thompson, A., Simonson, M., \& Hargrave, C. (1996). Educational technology: A review of the research (2nd ed.). Washington, DC: Association for Educational Communications and Technology.

U.S. Department of Education, National Center for Education Statistics. (2002). Technology in schools: Suggestions, tools, and guidelines for assessing technology in elementary and secondary education (NCES 2003-313). Washington, DC: National Center for Education Statistics.

Vanatta, R. A. (2000). Evaluation to planning: Technology integration in a school of education. Journal of Technology and Teacher Education, 8(3), 231-246.

White, N., Ringstaff, C., \& Kelley, L. (2002). Getting the most from technology in schools. Retrieved December 10, 2007, from WestEd Web site: http://www.wested.org/online_pubs/kn-02-01.pdf

Whitehead, B. M., Jensen, D. F. N., \& Boschee, F. (2003). Planning for technology: A guide for school administrators, technology coordinators, and curriculum leaders. Thousand Oaks, CA: Corwin Press. 


\begin{tabular}{|l|c|c|c|c|c|c|c|c|c|c|}
\hline \multicolumn{2}{|l|}{ Table 1. Frequency of Technology Planning } & & & & $03-04 / 04-05$ & $03-04 / 05-06$ & \multicolumn{2}{|c|}{$04-05 / 05-06$} \\
\hline \multicolumn{1}{|c|}{ Revision Frequency Category } & $03-04$ & $04-05$ & $05-06$ & $\chi^{2}$ & Sig. & $\chi^{2}$ & Sig. & $\chi^{2}$ & Sig. \\
\hline Annual revision & $70 \%$ & $73 \%$ & $86 \%$ & 6.33 & $*$ & 118.5 & $* *$ & 89.4 & $* *$ \\
\hline Every 2 years & $4 \%$ & $7 \%$ & $3 \%$ & 9.05 & $* *$ & 5.47 & $* *$ & 28.8 & $* *$ \\
\hline Every 3 years & $10 \%$ & $7 \%$ & $3 \%$ & 10.2 & $* *$ & 55.88 & $* *$ & 25.8 & $* *$ \\
\hline Every 4 to 5 years & $6 \%$ & $5 \%$ & $3 \%$ & 4.36 & $*$ & 17.33 & $* *$ & 5.43 & $*$ \\
\hline No set revision policy & $9 \%$ & $8 \%$ & $5 \%$ & 2.07 & & 14.33 & $* *$ & 7.49 & $* *$ \\
\hline$*$ Significant at $\alpha<.05$ level \\
$* *$ Significant at $\alpha<.01$ level
\end{tabular}

\begin{tabular}{|c|c|c|c|c|c|c|c|c|c|}
\hline & & & & 03-04 & $4-05$ & $03-04$ & $05-06$ & $04-0$ & $5-06$ \\
\hline Alignment Category & $03-04$ & $04-05$ & $05-06$ & $\chi^{2}$ & Sig. & $\chi^{2}$ & Sig. & $\chi^{2}$ & Sig. \\
\hline Approved by the SAC & $69 \%$ & $64 \%$ & $63 \%$ & 10.7 & $* *$ & 11.81 & $* *$ & 0.22 & \\
\hline Created and/or revised as part of SIP & $80 \%$ & $71 \%$ & $72 \%$ & 35.4 & $* *$ & 21.21 & $* *$ & 1.16 & \\
\hline Aligned with district technology plan & $84 \%$ & $91 \%$ & $90 \%$ & 33 & $* *$ & 18.3 & $* *$ & 1.93 & \\
\hline Reflects data from our STAR Profile & $55 \%$ & $49 \%$ & $55 \%$ & 10.8 & $* *$ & 0 & & 11.6 & $* *$ \\
\hline Reflects the goals of the EETT, NCLB & & $54 \%$ & $49 \%$ & & & & & 11.1 & $* *$ \\
\hline \multicolumn{10}{|c|}{$\begin{array}{l}* \text { Significant at } \alpha<.05 \text { level } \\
* * \text { Significant at } \alpha<.01 \text { level } \\
\text { SAC = school advisory council } \\
\text { SIP = school improvement plan } \\
\text { NCLB = No Child Left Behind } \\
\text { EETT = Enhancing Education Through Technology }\end{array}$} \\
\hline
\end{tabular}


Table 3. Technology Plan Focus

\begin{tabular}{|l|c|c|c|c|c|c|c|c|c|}
\hline & & & & $03-04 / 04-05$ & \multicolumn{2}{c|}{$03-04 / 05-06$} & \multicolumn{2}{c|}{$04-05 / 05-06$} \\
\hline \multicolumn{1}{|c|}{ Focus Category } & $03-04$ & $04-05$ & $05-06$ & $\chi^{2}$ & Sig. & $\chi^{2}$ & Sig. & $\chi^{2}$ & Sig. \\
\hline Access and skills for all students & $11 \%$ & $46 \%$ & $47 \%$ & 489.3 & $* *$ & 508.8 & $* *$ & 0.35 & \\
\hline Integrating subject-area instruction & $65 \%$ & $48 \%$ & $44 \%$ & 94.41 & $* *$ & 131.2 & $* *$ & 4.46 & $*$ \\
\hline $\begin{array}{l}\text { Procuring/maintaining hardware/soft- } \\
\text { ware }\end{array}$ & $10 \%$ & $4 \%$ & $6 \%$ & 37.4 & $* *$ & 9.76 & $* *$ & 7.12 & $* *$ \\
\hline $\begin{array}{l}\text { Technology for select students } \\
\text { Technology for administrative tasks }\end{array}$ & $13 \%$ & $1 \%$ & $0 \%$ & 149.8 & $* *$ & 162.3 & $* *$ & 0.6 & \\
\hline $\begin{array}{l}* \text { Significant at } \alpha<.05 \text { level } \\
* * \text { Significant at } \alpha<.01 \text { level }\end{array}$ & $1 \%$ & $2 \%$ & 0.04 & & 1.69 & & 2.08 & \\
\hline
\end{tabular}

\begin{tabular}{|l|c|c|c|c|}
\hline \multicolumn{1}{|l|}{ Table 4. Technology Planning Stakeholders } \\
\hline & & & $04-05 / 05-06$ \\
\hline \multicolumn{1}{|c|}{ Stakeholder } & $04-05$ & $05-06$ & $\chi^{2}$ & Sig. \\
\hline Administrators & $97 \%$ & $99 \%$ & 6.26 & $*$ \\
\hline Business leaders & $21 \%$ & $21 \%$ & 0.02 & \\
\hline Community members & $37 \%$ & $39 \%$ & 1.96 & \\
\hline Consortia & $3 \%$ & $3 \%$ & 0.45 & \\
\hline District technology leaders & $54 \%$ & $55 \%$ & 0.86 & \\
\hline Parents & $53 \%$ & $56 \%$ & 4.23 & $*$ \\
\hline Students & $21 \%$ & $25 \%$ & 11 & $* *$ \\
\hline Teachers & $95 \%$ & $97 \%$ & 11.5 & $* *$ \\
\hline Technology specialists & $90 \%$ & $89 \%$ & 2.47 & \\
\hline$*$ Significant at $\alpha<.05$ level \\
$* *$ Significant at $\alpha<.01$ level & & & & \\
\hline
\end{tabular}




\begin{tabular}{|c|c|c|c|c|c|c|c|c|c|}
\hline Table 5. Trends in School Hardware and Software Funding Needs \\
\hline & & & & $03-04 / 04-05$ & $03-04 / 05-06$ & \multicolumn{2}{l|}{$04-05 / 05-06$} \\
\hline Technology Funding Category & $03-04$ & $04-05$ & $05-06$ & $\chi^{2}$ & Sig. & $\chi^{2}$ & Sig. & $\chi^{2}$ & Sig. \\
\hline Hardware Funding Needs & & & & & & & & & \\
\hline Maintain level of technology (MLT) & $80 \%$ & $55 \%$ & $56 \%$ & 231.17 & $* *$ & 227.47 & $* *$ & 0.05 & \\
\hline Cannot MLT & $20 \%$ & $45 \%$ & $44 \%$ & 231.17 & $* *$ & 227.47 & $* *$ & 0.05 & \\
\hline Software Funding Needs & & & & & & & & & \\
\hline $\begin{array}{l}\text { Maintain level of technology (MLT) } \\
\text { Cannot MLT }\end{array}$ & $76 \%$ & $59 \%$ & $58 \%$ & 121.39 & $* *$ & 137.07 & $* *$ & 1.17 & \\
\hline $\begin{array}{l}\text { Cagnificant at } \alpha<.05 \text { level } \\
* * \text { Significant at } \alpha<.01 \text { level } \\
\text { MLT=Maintain level of technology }\end{array}$ & $24 \%$ & $41 \%$ & $42 \%$ & 121.39 & $* *$ & 137.07 & $* *$ & 1.17 & \\
\hline
\end{tabular}

\begin{tabular}{|l|l|l|l|l|}
\hline \multicolumn{2}{|c|}{ Table 6. Primary Funding Sources } & & & \multicolumn{2}{c|}{$04-05 / 05-06$} \\
\hline \multicolumn{1}{|c|}{ Funding Category } & $04-05$ & $05-06$ & \multicolumn{1}{c|}{$\chi^{2}$} & Sig. \\
\hline A+/School recognition & $20 \%$ & $21 \%$ & 2.17 & \\
\hline Profits from school ventures & $21 \%$ & $23 \%$ & 4.37 & $*$ \\
\hline Title I funds & $37 \%$ & $39 \%$ & 4.07 & $*$ \\
\hline School Improvement funds & $49 \%$ & $51 \%$ & 2.42 & \\
\hline Other funds & $28 \%$ & $16 \%$ & 138 & $* *$ \\
\hline No other school funds are currently earmarked & $14 \%$ & $9 \%$ & 35.8 & $* *$ \\
\hline $\begin{array}{l}* \\
* * \text { Significant at } \alpha<.05 \text { level }\end{array}$ & & & & \\
\hline
\end{tabular}




\begin{tabular}{|c|c|c|c|c|c|c|c|c|c|}
\hline \multicolumn{2}{|l|}{ Table 7. Other Technology Funding Sources } \\
\hline
\end{tabular}

\begin{tabular}{|l|c|c|c|c|c|c|c|c|c|c|}
\hline Table 8. School Socioeconomic Status and School Hardware and Software Funding Needs \\
\hline & \multicolumn{3}{|c|}{ Low SES } & \multicolumn{3}{c|}{ High SES } & \multicolumn{3}{c|}{ Main } & \multicolumn{2}{c|}{ Interaction } \\
\hline Technology Funding Category & $03-04$ & $04-05$ & $05-06$ & $03-04$ & $04-05$ & $05-06$ & $\chi^{2}$ & Sig. & $\chi^{2}$ & Sig. \\
\hline Hardware Funding Needs & & & & & & & & & & \\
\hline MLT & $76 \%$ & $56 \%$ & $57 \%$ & $84 \%$ & $54 \%$ & $55 \%$ & 288.85 & $* *$ & 11 & $* *$ \\
\hline Cannot MLT & $24 \%$ & $44 \%$ & $43 \%$ & $16 \%$ & $46 \%$ & $45 \%$ & 288.85 & $* *$ & 11 & $* *$ \\
\hline Software Funding Needs & & & & & & & & & & \\
\hline MLT & $75 \%$ & $57 \%$ & $60 \%$ & $76 \%$ & $62 \%$ & $56 \%$ & 171.97 & $* *$ & 9.46 & $* *$ \\
\hline Cannot MLT & $25 \%$ & $43 \%$ & $40 \%$ & $24 \%$ & $38 \%$ & $44 \%$ & 171.97 & $* *$ & 9.46 & $* *$ \\
\hline $\begin{array}{l}* \text { Significant at } \alpha<.05 \text { level } \\
* * \text { Significant at } \alpha<.01 \text { level } \\
\text { MLT=Maintain level of technology }\end{array}$
\end{tabular}




\begin{tabular}{|c|c|c|c|c|c|c|c|c|c|c|}
\hline \multirow[b]{2}{*}{ Funding Sources } & \multicolumn{3}{|c|}{ Low SES } & \multicolumn{3}{|c|}{ High SES } & \multicolumn{2}{|c|}{ Main } & \multicolumn{2}{|c|}{ Interaction } \\
\hline & $03-04$ & $04-05$ & $05-06$ & $03-04$ & $04-05$ & 05-06 & $\chi^{2}$ & Sig. & $\chi^{2}$ & Sig. \\
\hline \multicolumn{11}{|l|}{ Technology Funds Sought } \\
\hline Federal or state grants & $39 \%$ & $36 \%$ & $29 \%$ & $25 \%$ & $21 \%$ & $17 \%$ & 71.02 & $* *$ & 0.84 & \\
\hline Private grants & $15 \%$ & $10 \%$ & $10 \%$ & $15 \%$ & $11 \%$ & $15 \%$ & 4.66 & $*$ & 3.95 & \\
\hline Business partnerships & $27 \%$ & $25 \%$ & $27 \%$ & $32 \%$ & $28 \%$ & $27 \%$ & 2.71 & & 2.29 & \\
\hline Donations & $25 \%$ & $25 \%$ & $26 \%$ & $35 \%$ & $31 \%$ & $33 \%$ & 27.19 & $* *$ & 2.19 & \\
\hline Foundations & $10 \%$ & $9 \%$ & $7 \%$ & $13 \%$ & $14 \%$ & $11 \%$ & 11.55 & $* *$ & 0.91 & \\
\hline Fund-raisers & $22 \%$ & $12 \%$ & $18 \%$ & $38 \%$ & $33 \%$ & $36 \%$ & 126.5 & $* *$ & 3.24 & \\
\hline Additional funds not sought & $23 \%$ & $19 \%$ & $21 \%$ & $17 \%$ & $14 \%$ & $14 \%$ & 18.6 & $* *$ & 0.73 & \\
\hline \multicolumn{11}{|c|}{ Technology Funds Awarded } \\
\hline Federal or state grants & $31 \%$ & $35 \%$ & $30 \%$ & $16 \%$ & $17 \%$ & $13 \%$ & 123.7 & $* *$ & 1.07 & \\
\hline Private grants & $9 \%$ & $5 \%$ & $6 \%$ & $11 \%$ & $6 \%$ & $8 \%$ & 2.92 & & 0.07 & \\
\hline Business partnerships & $12 \%$ & $12 \%$ & $13 \%$ & $16 \%$ & $16 \%$ & $16 \%$ & 7.86 & $*$ & 0.27 & \\
\hline Donations & $17 \%$ & $16 \%$ & $17 \%$ & $31 \%$ & $27 \%$ & $31 \%$ & 78.86 & $* *$ & 0.86 & \\
\hline Foundations & $5 \%$ & $7 \%$ & $4 \%$ & $9 \%$ & $11 \%$ & $9 \%$ & 19.71 & ** & 1.16 & \\
\hline Fund-raisers & $15 \%$ & $17 \%$ & $14 \%$ & $36 \%$ & $35 \%$ & $35 \%$ & 155.1 & $* *$ & 1.46 & \\
\hline
\end{tabular}




\section{Technology Planning Survey Items (2005-06)}

Which of the following characterize(s) your school's technology plan? (Check all that apply)

Our technology plan:

- has been approved by the School Advisory Council.

- was created and/or is revised as part of our School Improvement Plan.

- is a separate plan.

- None of these

Which of the following characterize(s) your school's technology plan or technology component of SIP? (Check all that apply)

Our technology plan or technology component of SIP:

- is aligned with our district technology plan.

- reflects data from our STAR Profile.

- reflects the goals of the Enhancing Education Through Technology Act (EETT, NCLB).

- was influenced by the Florida STAR Chart.

- None of the above.

How often is your technology plan or technology component of SIP revised? (Select one)

- Annually

- Every 2 years

- Every 3 years

- Every 4-5 years

- No set revision policy

Who actively participates in the technology planning process? (Check all that apply)

- Administrators

- Business leaders

- Community members

- Consortia

- District Technology Leaders

- Parents

- Students

- Teachers

- Technology specialists

- None of the above

\section{Technology Funding Survey Items (2005-06)}

We have adequate hardware funding for our school to: (Select one)

- maintain our current level of technology.

- maintain our current level of technology and all purchases necessary for desired growth.

- maintain our current level of technology and limited purchase of new equipment.

- support some hardware expenditures, but not enough to maintain our current level of technology.

- We do not have adequate funding to purchase or maintain hardware.

We have adequate software funding for our school to: (Select one)

- maintain our current level (Newly purchased machines have essentially the same applications as existing 
machines. No significant upgrading or additional software added to existing machines).

- $\quad$ provide for the purchase of all software necessary to provide for desired growth.

- $\quad$ provide for the purchase of some new or upgraded software.

- support some software expenditures, but not enough to maintain our current level of technology.

- We do not have adequate funding to purchase or update software

Other than the funds generally provided through the District (which include sales tax proceeds):

1. What additional sources of technology funding did your school actively seek for the 2004-05 school year?

2. What additional sources have you been awarded? (This does not include monies moved from one object code to another within the school. This is about generating ADDITIONAL funding.)

(Check all that apply)

Funds Sought

- Business partnerships

- Donations

- Foundation

- Fund-raisers

- District Grants

- Federal or state grants

- Private Grants

- PTA/PTO (or other school-related "booster" organizations)

- We have not sought additional technology funds this year.

(Check all that apply)

Funds Awarded

- Business partnerships

- Donations

- Foundation

- Fund-raisers

- District Grants

- Federal or state grants

- Private Grants

- PTA/PTO (or other school-related "booster" organizations)

Within your school, what other school funds are currently allocated for the support of technology? (Check all that apply)

- A+/School Recognition

- Profits from school ventures (cell towers, after-care, vending machines, Yearbook sales, etc.)

- Title I

- Title II or other Title programs

- Instructional Materials

- School Improvement

- Just Read Florida

- Other (please explain)

- No other school funds are currently earmarked for technology.

IJEPL is a joint publication of the Association for Supervision and Curriculum Development, the Faculty of Education at Simon Fraser University, and the College of Education and Human Development at George Mason University. By virtue of their appearance in this open access journal, articles are free to use, with proper attribution, in educational and other non-commercial settings 90 days after initial publication. Copyright for articles published in JJEPL is retained by the authors. More information is available on the IJEPL Web site: http://www.ijepl.org 